\title{
The forests and related vegetation of Kwerba, on the Foja Foothills, Mamberamo, Papua (Indonesian New Guinea)
}

\author{
M. van Heist ${ }^{1,2}$, D. Sheil ${ }^{1,2}$, I. Rachman ${ }^{3}$, P. Gusbager ${ }^{4}$, C.O. Raweyai ${ }^{4}$, H.S.M. Yoteni ${ }^{5}$
}

Key words

biogeography

botanical collection

endemism

undescribed taxa

wilderness

\begin{abstract}
We describe the vegetation of Kwerba, in the foothills of the Foja Mountains in the Mamberamo Basin of West Papua, Indonesia. Few surveys have been carried out in this remote area of Western New Guinea. Working in collaboration with local people we made 15 plots, 10 in primary forest, 3 in secondary forest and 2 in gardens. A total of 487 morpho-species were distinguished, of which $32 \%$ (156) did not match any herbarium specimens or published reference. Tree densities ( $598 \pm 136 / \mathrm{ha})$ are similar to lowland forests elsewhere, but mean stem sizes $(22 \pm 1 \mathrm{~cm}$ dbh and $21 \pm$ $2 \mathrm{~m}$ height for trees over $10 \mathrm{~cm}$ dbh) appear small. Numbers of tree species per plot $(22 \pm 4$, of 40 stems recorded) are unremarkable, but levels of endemism are potentially high with many of the unidentified species being rare (seldom collected) or undescribed. This is the first quantitative description of vegetation in Kwerba, Foja and Mamberamo, and joins only a handful of such studies in Papua. Additional botanical and ecological survey effort is greatly needed in Mamberamo, and in New Guinea generally.
\end{abstract}

Published on 17 August 2010

\section{INTRODUCTION}

New Guinea comprises the greater part of the floristic region called 'Papuasia'; a centre for floristic diversity (Marshall \& Beehler 2007). Papua, formerly 'Irian Jaya', is the western, Indonesian, part of New Guinea island. Papua harbours the largest tract of old growth tropical forest wilderness in Asia Pacific region (Beehler 2007). The province contains a vast array of habitats. Limited access for foreign researchers, especially in recent decades, has resulted in Papua's flora being largely unknown (Polak 2000) though experts estimate that 14000 to 25000 plant species occur in New Guinea as a whole (Womersley 1978, Davis et al. 1995, Supriatna et al. 1999, Frodin 2001, Roos et al. 2004) and that around 40-50\% are likely endemic (Roos et al. 2004). Here we describe the vegetation of Kwerba in the foothills of the Foja Mountains, Mamberamo, Papua - an area where botanical information is required to guide conservation (Supriatna et al. 1999).

Until recently, Papua's forests had largely escaped the destruction seen in Indonesia's western provinces. This is changing. Between 1993 and 1997, Papua's forest cover decreased from c. 90 (Biodiversity Action Plan for Indonesia, Ministry of National Development Planning 1993) to c. 80 \% (Supriatna et al. 1999). Transmigration, plantation agriculture, mining, oil and gas exploitation, dams and various other infrastructure projects now threaten Papua's forests. Most of these developments concern areas lacking any biological assessment, so the environmental and conservation implications remain uncertain. To confront this ongoing problem, those responsible for conserving Papua's natural resources need more information and the capacity to use it.

\footnotetext{
Institute of Tropical Forest Conservation, Mbarara University of Science \& Technology, P.O. Box 44, Kabale, Uganda; corresponding author e-mail: miriamvanheist@itfc.org.

2 CIFOR, P.O. Box 6596 JKPWB, Jakarta 10065, Indonesia.

${ }^{3}$ Herbarium Bogoriense, LIPI, Bogor.

4 UNIPA Manokwari.

${ }^{5}$ Conservation International-Papua.
}

In 1999 a group of experts evaluating regional conservation priorities stated that the Mamberamo Basin is "Papua's most important terrestrial biodiversity resource" (Supriatna et al. 1999). They recommended both biological and social surveys in the area. Within this area the Foja Mountains had already been highlighted as an area of considerable biological significance (Diamond 1982, 1985). The study we report here is the result of a pilot training project - a collaboration between Conservation International (Cl), the Indonesian Institute of Sciences (LIPI) and the Center for International Forestry Research (CIFOR) - that set out to rapidly assess and describe local patterns of vegetation in conjunction with local people and local post graduate students (CIFOR 2004).

\section{Context}

The Foja Mountains (sometimes called the 'Gauttier Mountains' in older references) recently gained international recognition with the widely publicised discovery of several new, or long-lost, species of animals and plants (Anonymous 2006a, b, Cyranoski 2006, Beehler et al. 2007). The Foja are shared between the traditional territories of Kwerba and Papasena villages. Here we describe a survey on the mountain footslopes around Kwerba. A key result of our work was the trust established with local communities, who are often suspicious of outsiders (and with good reason). This ultimately ensured $\mathrm{Cl}$ and LIPI the required local permission to undertake their well publicised work in the sacred mountains (Sheil \& Boissière 2006).

The history of biological exploration in Papua is summarised in the Ecology of Papua (Marshall \& Beehler et al. 2007). Here we briefly consider studies near the Foja Mountains. Past studies in the area are few (see Richards \& Suryadi 2002). In 1920, Kremer explored nearby Dabra village and adjacent mountains and generated a brief botanical account. The 1938 Archbold Expedition was probably the most significant scientific exploration of the Mamberamo Basin and resulted in several publications (see Archbold et al. 1942), but the explorations did not include Kwerba or the Foja. More than 40 years later Jared Diamond used helicopter access to carry out the first 
ornithological surveys of the Foja Mountains and highlighted their regional significance (Diamond 1982, 1985). Cl performed a rapid survey in the lowlands in 2000 , again close to Dabra (Richards \& Suryadi 2002). Next came our survey (in Kwerba as detailed here, and in Papasena, both in 2004), and then the LIPI-CI Foja surveys in 2005 and 2007. The study we detail here is, as far as we know, the first quantitative description of vegetation in the region.

\section{METHODS}

\section{Description of the research site}

The Mamberamo Basin encompasses 7.8 million ha covering much of northwest New Guinea. Altitude ranges from nearly sea level to $2193 \mathrm{~m}$ in the Foja Mountains and 5030 $\mathrm{m}$ on Mt Jayawijaya. These mountains, like those in the rest of Papua, are geologically young, originating in the middle to late Miocene (c. 10 million years ago) (Morley 2000). The Foja massif, encompassing $\sim 300000$ ha, is an isolated linear range (west-northwest to east-southeast) with several summits above $2000 \mathrm{~m}$ (Beehler et al. 2007). The Foja region remains tectonically active. Much of the flatter lowlands are alluvial plains subjected to seasonal flooding. Climate records are not available, due to an absence of weather stations, but most of the area supports a wet rain forest climate (Richards \& Suryadi 2002). Regional population densities in the Mamberamo Ba$\mathrm{sin}$ are less than one person per $\mathrm{km}^{2}$. The Foja uplands have never supported intensive cultivation comparable with that seen in the central highlands of New Guinea (e.g. Humphreys \& Brookfield 1991).

Kwerba lies on the foothills of the Foja Mountains, just below the confluence of the Tariku and the Taritatu rivers, from where the river is called Mamberamo (see Fig. 1). Maps are limited. There are no roads and communication between villages is on foot, by boat or by light plane. Participatory mapping suggests Kwerba's territory covers between 1000 and $2000 \mathrm{~km}^{2}$ and a population density of around $0.3-0.5$ people per $\mathrm{km}^{2}$ (Boissière et al. 2007).

\section{Sampling methods}

A full description of our approach and methods is given by Sheil et al (2003c). The field survey was part of a larger study to assess biodiversity and its importance to local people, a multidisciplinary approach previously developed with communities in Kalimantan (Indonesian Borneo) (Sheil et al. 2003c, 2005). First we built a shared understanding of landscape classification and terminology through a variety of activities including participatory mapping of land types and resources on an accurate basemap of major rivers. Community members guided us through their main terms for different land types. Representative sites were then visited for field evaluation. We allocated most sampling efforts within the natural forests, as we believed these would be the most variable and species rich, but we also sought comparison with secondary and cultivated land as these are of clear significance to the people. Walking distance from the village was limited to $2-3$ hours. In one case (F4), a boat trip down the river allowed for sampling further away from the village, and reaching the lakeside forest F6 took 4 hours.

Having arrived at the general area to be sampled, a random list of numbers would determine the starting point and direction of a 40 meter transect line along which all recordings were taken. For each transect standard descriptions of terrain included location, GPS readings, accessibility, slope position, steepness and aspect, altitude, surrounding land types and nearest water features. A soil profile was excavated in the middle of each transect, in addition two holes were augured at $10 \mathrm{~m}$ and $30 \mathrm{~m}$ along the transect. Profile horizons were described in terms of depth, colour, texture, structure, consistency and $\mathrm{pH}$ while

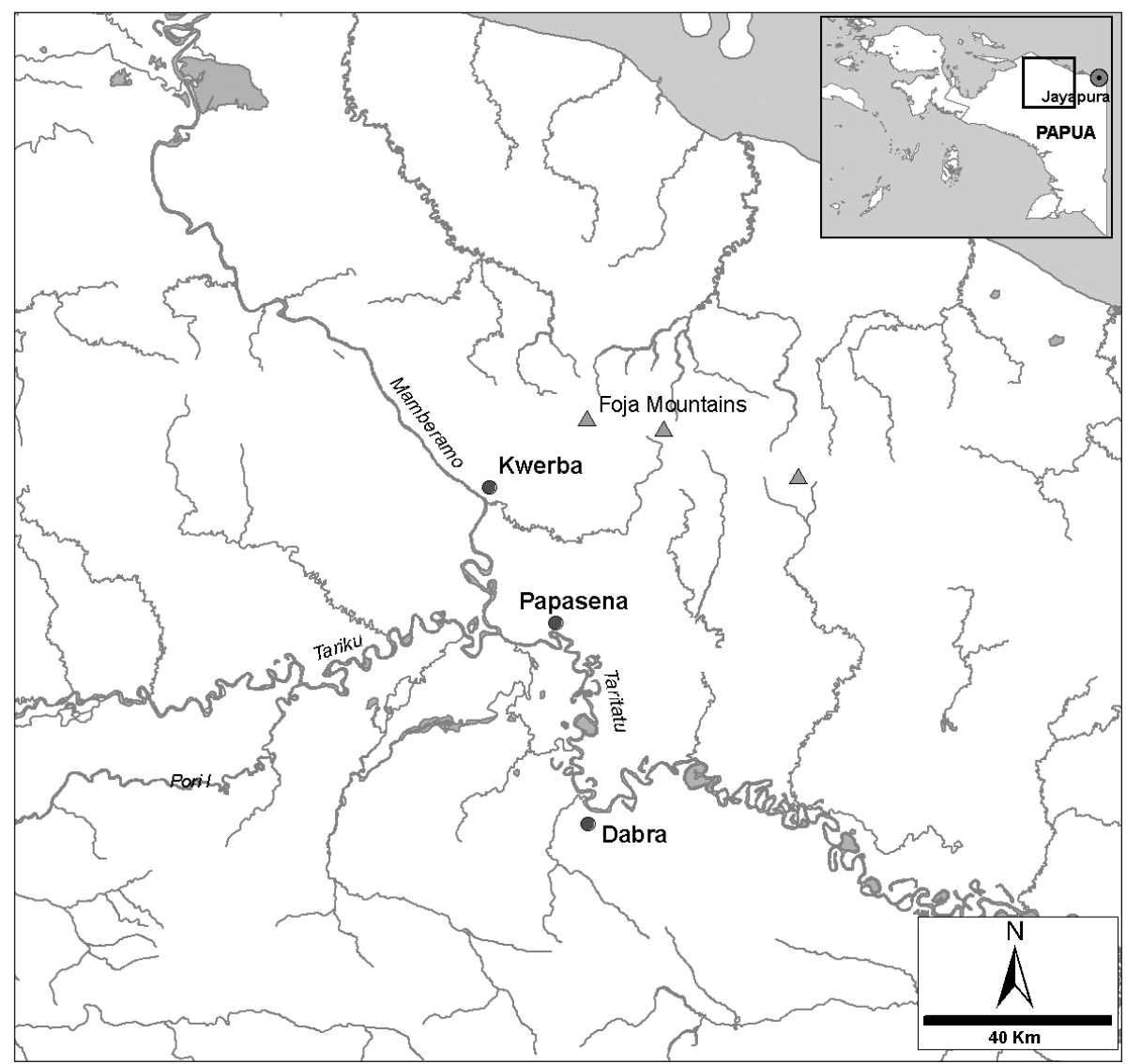

Fig. 1 The location of the Mamberamo basin, Foja Mountains and Kwerba village (see inset: top right for Papua, western New Guinea). 


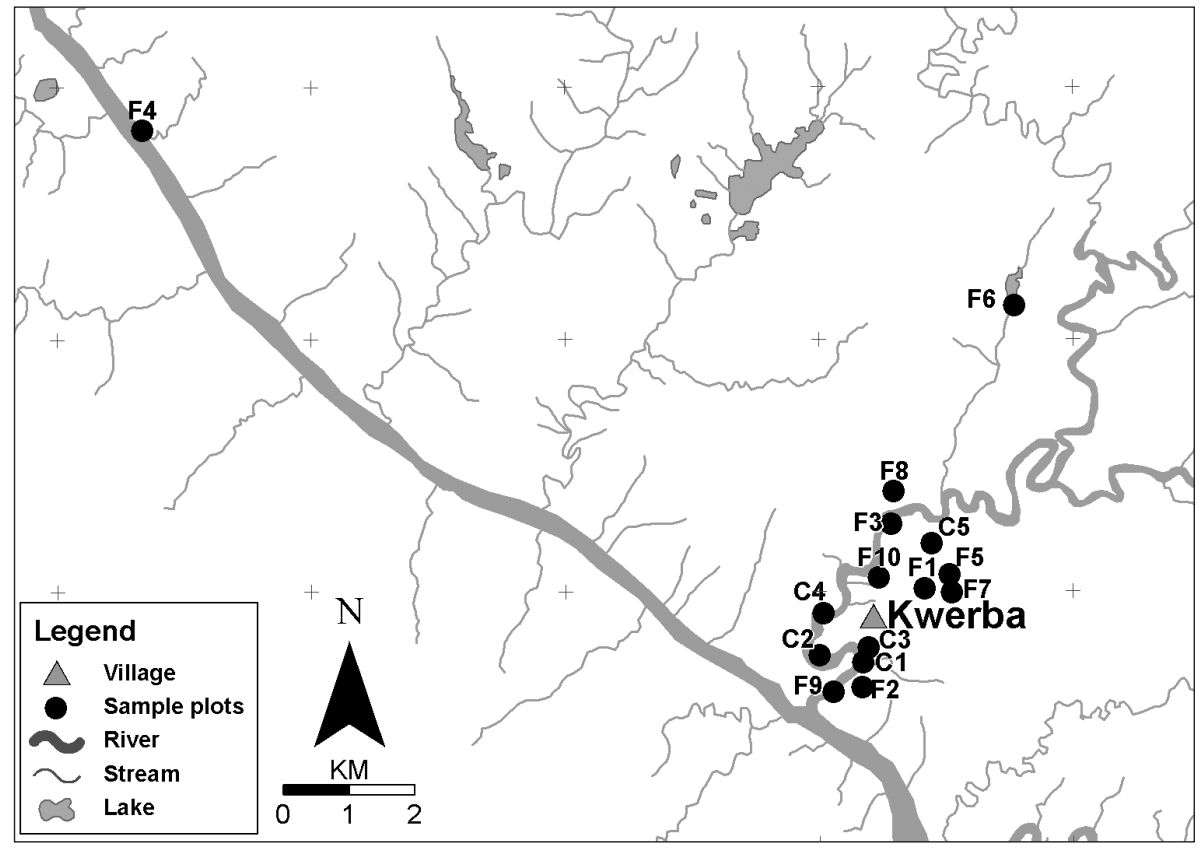

Fig. 2 The distribution of the 15 plots around Kwerba, and their type.

moisture regime, matrix node, pores, and roots were also assessed (all soil descriptions followed Suwardi \& Wiranegara 1998). Composite soil samples were taken from $0-20 \mathrm{~cm}$ and 21-40 cm for laboratory analysis.

The transect was divided into 10 subunits of 4 by 5 meter to record 'non trees'; herbs, ferns, climbers (over $1.5 \mathrm{~m}$ long), epiphytes below $2 \mathrm{~m}$ high and all monocots were identified and recorded as present or absent in each of the 10 subunits. Seedlings, saplings and shrubs were only recorded subjectively as 'the three most dominant species per plot'. A reference collection, including fertile material when possible, was made for verification and identification in the Bogor Herbarium. Our botanical nomenclature follows Brummitt (1992) and the names used in Bogor were checked and updated through the online International Plant Names Index (http://www.ipni.org, last accessed 31 December 2008).

A variable area sample unit, suitable for rapid assessments in heterogeneous forests (Sheil et al. 2003a) was used to record trees. In 8 subunits on both sides of $10 \mathrm{~m}$ sections along the $40 \mathrm{~m}$ transect, the 5 nearest trees (of $>10 \mathrm{~cm}$ dbh at $1.3 \mathrm{~m}$ ) were recorded; thus species, height and girth of a maximum of 40 trees would be assessed for each sample site, which allows calculations of density and basal area. In addition, the furcation index of each tree was recorded ( $F$-index, a rapid visual estimate of the $\%$ of plant height from the top down, where apical dominance is no longer a property of a single clearly defined stem and is recorded on a scale of 0 to $110 \%$ ) (Gillison \& Carpenter 1997). Tree richness was summarized using Fisher's Alpha (Fisher et al. 1943) and a simpler index 'Log [number of species]/log [number of stems]' (a measure recommended for small samples) (Sheil et al. 1999), to allow comparison with other studies.

Our small plot sizes and limited replication mean that our account, though quantitative, should be considered provisional and descriptive. We do not believe more sophisticated analyses are useful without further replicates or larger samples.

\section{RESULTS}

\section{Observations on terrain and soils}

The terrain around Kwerba is rugged, with steep deeply incised landforms rising above more level riverside swamps. The area is geologically young and dynamic, and landslides are common. We observed (through drilling of soil cores and examining outcrops) that sandstone and siltstone dominate the visible bedrock in the region. The hills show many occur-

Table 1 Average characteristics, per cover type. Data for all 15 plots is presented in Appendix B.

\begin{tabular}{|c|c|c|c|c|c|c|c|c|c|c|}
\hline $\begin{array}{l}\text { Cover } \\
\text { type }\end{array}$ & $\begin{array}{l}\text { Stem density } \\
\text { per ha }\end{array}$ & $\mathrm{BA} \mathrm{m} \mathrm{m}^{2} / \mathrm{ha}$ & $\begin{array}{l}\text { Average dbh } \\
(\mathrm{cm})\end{array}$ & $\begin{array}{l}\text { Max dbh } \\
(\mathrm{cm})\end{array}$ & $\begin{array}{l}\text { Average } \mathrm{Ht} \\
(\mathrm{m})\end{array}$ & $\begin{array}{l}\text { Average } \\
\text { F-index }\end{array}$ & $\begin{array}{l}\text { StdDev } \\
\text { F-index }\end{array}$ & $\begin{array}{l}\text { Nr of tree } \\
\text { species } \\
\text { (not planted) }\end{array}$ & $\begin{array}{l}\text { Log Nr spec/ } \\
\text { Log Nr stems }\end{array}$ & $\begin{array}{l}\mathrm{Nr} \text { of } \\
\text { herbs etc* }\end{array}$ \\
\hline \multicolumn{11}{|c|}{ Primary forest (10 plots) } \\
\hline Average & 598.2 & 32.4 & 22.0 & 63.9 & 21.0 & 11.9 & 16.3 & 22.1 & 0.8 & 52.7 \\
\hline Std dev. & 136.0 & 12.0 & 1.0 & 16.8 & 2.3 & 5.7 & 4.7 & 3.5 & 0.04 & 16.9 \\
\hline \multicolumn{11}{|c|}{ Former cultivation 1 (3 plots) } \\
\hline Average & 676.3 & 19.2 & 18.0 & 41.3 & 13.0 & 38.9 & 38.3 & 15.7 & 0.7 & 52.0 \\
\hline \multicolumn{11}{|c|}{ Cultivation ${ }^{2}$ (2 plots) } \\
\hline Average & 235.5 & 10.2 & 22.0 & 38.3 & 13.1 & 30.9 & 42.0 & 7.5 & 0.7 & 40.0 \\
\hline Std dev. & 99.7 & 2.1 & 2.6 & 6.7 & 1.7 & 2.8 & 2.6 & 3.5 & 0.1 & 1.4 \\
\hline
\end{tabular}


rences of harder (probably igneous) rock. Soils are generally coarse and sandy, acidic, with limited cation exchange capacity (average ECEC for cultivated plots is $17.7 \mathrm{me} / 100 \mathrm{mg}$ and for forest plots $14.0 \mathrm{me} / 100 \mathrm{mg})$, low organic carbon $(2.4 \%$ and $1.7 \%$, respectively) and low phosphorus (average $\mathrm{P}_{2} \mathrm{O}_{5}$ of 8.5 and $23.2 \mathrm{ppm}$, respectively) and potassium (average $\mathrm{K}_{2} \mathrm{O}$ of 83.2 and $110.1 \mathrm{ppm}$, respectively). Soil drainage was generally impeded. Inceptisols and Entisols dominate amongst the plots (with 10 and 3 plots each), while the two other soil types (with one plot each) are a Histosol and Ultisol.

\section{Observations on cultivation}

Of the three formerly cultivated plots two were abandoned more than 20 years ago and one 6 years ago. The two cultivated plots were a sago garden and a mixed fruit garden, both on Entisols. Cultivation in the rugged terrain around Kwerba includes planted sago palms (Metroxylon sagu Rottb.), fruit trees like papaya (Carica papaya L.), star fruit (Averrhoa carambola L.), banana (Musa spp.), water apple (Syzygium aqueum Alston) and annual crops like sweet potato (Ipomoea batatas (L.) Lam.), cassava (Manihot utilissima Pohl) and taro (Xanthosoma spp.). Areas for planting are selected for ease of access, and for soil suitability. In general this shifting cultivation involves little clearing and fire is not always used, unlike swidden cultivation in other tropical regions which is considered synonymous with 'slash-and-burn' (e.g. Mertz 2002). Sago, the main staple, is generally restricted to wet sites in the alluvial plains and localised valleys.

\section{The plots}

Locations and site descriptions for the 15 plots (local name, geographic coordinates, altitude, terrain, soil, vegetation type and human influence) are provided in Appendix A and Fig. 2 shows their distribution around Kwerba. For summary purposes, we group plots into three types: primary forest (F1 to F10), former cultivation (C1 to C3) and current cultivation (C4 and C5). The primary forests were never cleared for cultivation, nor did large scale tree felling occur, but cut stems were noted in most plots. One primary forest plot on the side of a lake (plot F6), considered sacred, is totally undisturbed.

\section{Quantitative vegetation description}

Average basal area of the ten primary forest plots is about $50 \%$ higher than that of former cultivated ones, and so are maximum tree diameter and average height. Of the three formerly cultivated plots, the more recently abandoned has a much higher stem density than the two older plots, but stems are thinner and shorter on average (see Table 1 and Appendix B).

Even in primary forest plots mean tree height seldom exceeds $25 \mathrm{~m}$, despite the occasional presence of taller emergents (Intsia bijuga Kuntze, Teijsmanniodendron spp., Ficus spp., Canarium maluense Lauterb., Hopea novoguineensis Slooten). In formerly and currently cultivated plots average tree height stays well below $15 \mathrm{~m}$ and the tallest trees seldom exceed $20 \mathrm{~m}$ (NB: a 65 m Ficus variegata Blume occurs in plot C2, likely a relic that survived from the original forest). Average diameter

Table 2 Matrix of shared and abundant species per sample (basal area, in $\mathrm{m}^{2} / \mathrm{ha}$ ), ordered by cover type.

\begin{tabular}{|c|c|c|c|c|c|c|c|c|c|c|c|c|c|c|c|}
\hline \multirow{2}{*}{$\begin{array}{l}\text { Plots in : } \\
\text { Species name }\end{array}$} & \multicolumn{10}{|c|}{ Primary forest } & \multicolumn{3}{|c|}{ Former cultivation } & \multicolumn{2}{|c|}{ Cultivation } \\
\hline & $\mathrm{F} 1$ & $\mathrm{~F} 2$ & F3 & $\mathrm{F} 4$ & F5 & $\mathrm{F} 6$ & $\mathrm{~F} 7$ & F8 & F9 & F10 & $\mathrm{C} 1$ & $\mathrm{C} 2$ & $\mathrm{C} 3$ & $\mathrm{C} 4$ & C5 \\
\hline \multicolumn{16}{|l|}{ Teijsmanniodendron } \\
\hline bogoriense Koord. & 1.2 & 1.1 & 1.8 & & 0.2 & & 1.3 & & & & 0.3 & & & & \\
\hline \multicolumn{2}{|l|}{ Pimelodendron amboinicum Hassk. } & 0.1 & 1.7 & 1.2 & 1.1 & 12.2 & & & & 2.1 & & & & & \\
\hline Cleistanthus myrianthus Kurz & 3.2 & 0.1 & 2.4 & 0.1 & 0.6 & 2.4 & & & & & & & & & \\
\hline Myristica fatua Houtt. & 0.2 & 0.6 & & 2.7 & 0.9 & & & & & & & & & & \\
\hline \multicolumn{15}{|l|}{ Medusanthera laxiflora } & \\
\hline \multicolumn{15}{|l|}{ Neoscortechinia forbesii } & \\
\hline Vatica rassak Blume & 21.4 & & & & & 0.8 & & & & & & 0.3 & & & \\
\hline Hopea novoguineensis Slooten & 1.9 & & & & 16.1 & 0.3 & 0.2 & 1.9 & 0.3 & & & & & & \\
\hline \multicolumn{15}{|l|}{ Teijsmanniodendron hollrungii } & \\
\hline Intsia bijuga Kuntze & 22.9 & & & 2.5 & & & 1.0 & 0.8 & 9.2 & 4.9 & & & & & \\
\hline $\begin{array}{l}\text { Citronella suaveolens } \\
\text { (Blume) R.A.Howard }\end{array}$ & 2.1 & \multicolumn{13}{|c|}{ Citronella suaveolens } & \\
\hline Cynometra sp. & & & & & & 0.2 & & & 0.2 & 0.1 & & & & & \\
\hline Gnetum gnemon L. & & & & & & & 0.2 & & 0.4 & 0.3 & & & & & \\
\hline \multicolumn{2}{|l|}{ Mastixiodendron pachyclados Melch. } & 5.4 & & & & & & & 1.2 & 1.3 & & & & & \\
\hline $\begin{array}{l}\text { Anisoptera thurifera ssp. polyandra } \\
\text { (Blume) P.S. Ashton }\end{array}$ & \multicolumn{5}{|c|}{ Anisoptera thurifera ssp. polyandra } & & & & 0.1 & 4.1 & 4.9 & & & & \\
\hline Horsfieldia sylvestris Warb. & & 3.5 & & & & & & 2.0 & & 0.3 & & & & & \\
\hline Pometia pinnata Forst. & & & 1.0 & 0.8 & & 6.7 & & 0.6 & 3.7 & 1.6 & & 0.8 & & & \\
\hline Myristica sp. & & & & 0.2 & 0.3 & & & & 5.9 & 0.1 & & & & & \\
\hline Canarium maluense Lauterb. & & & 0.1 & & 1.0 & 1.5 & 2.9 & 0.4 & & & & & & & \\
\hline Nauclea orientalis L. & & & 0.3 & & 0.3 & & & & 1.6 & & & & & & \\
\hline Ficus variegate Blume & & & & & & 0.8 & 0.2 & & 0.4 & & 0.3 & 8.7 & 1.7 & 0.0 & \\
\hline Pterocarpus indicus Willd. & & & & & & & 1.9 & & & & & 0.5 & & 0.5 & 0.1 \\
\hline Macaranga mappa Müll.Arg. & & & & & & & & & & & 0.4 & 1.0 & 0.1 & & \\
\hline Glochidion novo-guineense K.Schum & & & & & & & & & & & & 0.4 & 10.8 & & 0.1 \\
\hline Endospermum moluccanum Becc. & & & & & & & & & & & & 0.2 & 0.2 & 0.5 & \\
\hline
\end{tabular}


of the trees measured in each plot is only slightly higher in primary forest than in (formerly) cultivated, though more large trees occur in the former.

Plot level tree species richness is $50 \%$ higher in primary forest than in formerly cultivated plots and 3 times that in cultivated sites, though the Log $\mathrm{Nr}$ species/Log $\mathrm{Nr}$ of stems suggests that, when corrected for stem counts, the primary forest is only fractionally richer. Average numbers of non-tree species are not consistently different per plot between forest and formerly cultivated plots.

\section{Botanical overview}

In total, 487 different morpho-species were distinguished in the 15 plots. These belong to 284 identified genera in 98 different families. A third of these morpho-species remains unidentified: 132 are unidentified at species level, 23 at genus level and one at family level. The failure to match these taxa with herbarium material in Bogor, Java, suggests that most are absent from the herbarium. Some are likely to be undescribed species. The palms, Arecaceae, are especially diverse, with 38 morphospecies in 20 genera, though identification has proven difficult with eight unidentified genera and thirteen unidentified species. Orchidaceae follow, mostly represented by epiphytes.

\section{Trees}

In order to detect any systematic patterns in the forest types, we summarized the three most abundant tree species encountered in each variable area plot (see Appendix C). We then selected all such species which occurred in at least three plots, and developed a matrix of their basal area scores for each of the 15 plots, see Table 2.

In the primary forest, common canopy trees and emergents (that occur in 5 or more plots) are Teijsmanniodendron bogoriense and T. hollrungii, Cleistanthus myrianthus, Intsia bijuga, Canarium maluense and Pometia pinnata. In the second highest stratum, Anisoptera thurifera Blume subsp. polyandra, Hopea novoguineensis, Vatica rassak, Pimelodendron amboinicum, Mastixiodendron pachyclados, and Myristica fatua are often found. The lakeside forest (F6) has several species in common with other primary forest, with Pimelodendon amboinicum dominating, but a number of species were only recorded from there (thus not included in Table 2), such as Beilschmiedia myrmecophila Kosterm., Combretum trifoliatum Vent., and Pouteria macropoda (H.J.Lam) Baehni.

In formerly cultivated plots, pioneer trees like Ficus variegata are abundant, as well as Endospermum moluccanum, Glochidion novo-guineense and Macaranga mappa (the latter two were not encountered in forest plots at all). Other secondary tree species (less abundantly, hence not in Table 2) found in old fallows are Ficus miquelii King, Cananga odorata (Lam.) Hook.f. \& Thomson, Colona scabra Burret and Vitex parviflora A.Juss. Fruit trees include local species like Artocarpus communis J.R.Forst. \& G.Forst., Pometia pinnata, Artocarpus sp., Areca catechu L., Syzygium malaccense (L.) Merr. \& L.M.Perry and Citrus sp.

There is little overlap in tree species recorded from primary forest and formerly cultivated areas. Exceptions include Pometia pinnata, a wild fruit tree (Matoa) probably left standing when clearing an area for cultivation, as well as Ficus variegata and Vatica rassak. Our survey recorded Dipterocarpaceae 17 times, all but 2 of which were in primary forest plots; the five species were Vatica rassak (often of large diameter), and Vatica sp., Hopea novo-guineensis (an endemic and good timber species), Hopea sp. and Anisoptera thurifera ssp. polyandra (commonly occurring in groups in secondary forest). 
Table 4 Most frequently recorded species, trees and non-trees.

\begin{tabular}{|c|c|c|c|}
\hline Species & Family & $\begin{array}{l}\text { Life- } \\
\text { form* }\end{array}$ & $\begin{array}{l}\text { Recorded } \\
\text { (x out of y } \\
\text { plots) }\end{array}$ \\
\hline \multicolumn{4}{|c|}{ Most frequently recorded species in all 15 plots ( 8 times or more) } \\
\hline Flagellaria indica L. & Flagellariaceae & LL & $10 / 15$ \\
\hline Merremia peltata (L.) Merr. & Convolvulaceae & $\mathrm{LL}$ & $10 / 15$ \\
\hline Calamus hollrungii Becc. & Arecaceae & $\mathrm{PI}$ & $9 / 15$ \\
\hline Erycibe nitidula Pilg. & Convolvulaceae & WL & $9 / 15$ \\
\hline Riedelia corallina Valeton & Zingiberaceae & $\mathrm{H}$ & $9 / 15$ \\
\hline Scindapsus hederaceus Schott & Araceae & LL & $9 / 15$ \\
\hline Asplenium robustum Blume & Aspleniaceae & $\mathrm{F}$ & $8 / 15$ \\
\hline Cordyline terminalis Kunth & Agavaceae & $\mathrm{H}$ & $8 / 15$ \\
\hline Ficus sagittata Vahl & Moraceae & LFig & $8 / 15$ \\
\hline Phrynium macrocephalum K.Schum. & Marantaceae & $\mathrm{H}$ & $8 / 15$ \\
\hline Pothos versteegii Engl. & Araceae & $\mathrm{LL}$ & $8 / 15$ \\
\hline Rhaphidophora korthalsii Schott & Araceae & LL & $8 / 15$ \\
\hline Schismatoglottis calyptrata Zoll. \& Mor. & Araceae & $\mathrm{H}$ & $8 / 15$ \\
\hline \multicolumn{4}{|c|}{ Most frequently recorded species in 9 primary forest plots (6 times or more) } \\
\hline Asplenium robustum Blume & Aspleniaceae & $\mathrm{F}$ & $7 / 9$ \\
\hline Calamus hollrungii Becc. & Arecaceae & $\mathrm{PI}$ & $7 / 9$ \\
\hline Erycibe nitidula Pilg. & Convolvulaceae & WL & $7 / 9$ \\
\hline Pothos versteegii Engl. & Araceae & LL & $7 / 9$ \\
\hline Ficus sagittata Vahl & Moraceae & LFig & $6 / 9$ \\
\hline Flagellaria indica L. & Flagellariaceae & $\mathrm{LL}$ & $6 / 9$ \\
\hline Intsia bijuga Kuntze & Fabaceae & $\mathrm{T}$ & $6 / 9$ \\
\hline Piper majusculum Blume & Piperaceae & LL & $6 / 9$ \\
\hline Rhaphidophora korthalsii Schott & Araceae & LL & $6 / 9$ \\
\hline Riedelia corallina Valeton & Zingiberaceae & $\mathrm{H}$ & $6 / 9$ \\
\hline Scindapsus hederaceus Schott & Araceae & LL & $6 / 9$ \\
\hline Teijsmanniodendron bogoriense Koorc & Lamiaceae & $T$ & $6 / 9$ \\
\hline
\end{tabular}

* $\mathrm{F}=$ fern; $\mathrm{H}$ = herb; $\mathrm{LFig}=$ climbing fig; $\mathrm{LL}$ = non-woody liana; $\mathrm{PI}$ = palm; $\mathrm{T}$ = tree; $\mathrm{WL}=$ woody liana.

\section{Non-trees}

Records of the number of non-tree species in each plot are presented in Table 3, in order of overall species richness per lifeform.

The total number of non-tree species per plot ranges from 31 to 90. Species richness is particularly high for climbers (non-woody as well as woody lianas) and the Araceae family is dominant (Rhaphidophora spp., Pothos versteegii and Scindapsus hederaceus, followed by Convolvulaceae (Merremia peltata, Erycibe nitidula), Flagellariaceae (a single species, Flagellaria indica), Piperaceae (Piper spp.), Vitaceae (Cayratia spp., Tetrastigma spp., Cissus spp.), and several genera of Menispermaceae.

In Table 4, the most frequently recorded species (trees as well as non-trees) are listed.

Less common understorey taxa in primary forest include the gingers Riedelia spp., Etlingera sp., Costus speciosus Sm. (Zingiberaceae), the nettle Elatostema sp. (Urticaceae), Mapania sp. (Cyperaceae), Schismatoglottis calyptrata (Araceae) and a range of pteridophyte genera including Hymenophyllum, Selaginella, Blechnum, Lindsaea and Pneumatopteris.

\section{DISCUSSION}

\section{Local people}

Our rapid surveys were conducted with support from local communities. Local people made the surveys more effective, as they guided us to distinctive forests and helped us understand why these forests are important to them (for a discussion of these issues, see Sheil \& Lawrence 2004). We note the high level of knowledge the local people showed in virtually all aspects of the forest, including plants and plant use. We also emphasise that while people used the forest in many ways, the cultivated and modified areas are very localised, and even gardens have the structural appearance of forests (Sheil et al. 2003b, Boissiere et al. 2005).

\section{Soil}

The soils appear typical of West Papua where fertility is generally low (Subagjo et al. 2000). We recognise some variation in soil characteristics related to location and parent material. More work is needed to clarify if there is any relationship with vegetation beyond the trivial observation that swamp vegetation (and sago cultivation), is limited to the flat lowlands and poorly drained sites in the foothills where Entisols predominate.

\section{Identification}

Identification of plants proved challenging. Those undertaking botanical research in areas that are both extremely rich in species, and poorly known, should of course anticipate difficulties in obtaining definitive species identifications - but it is hard to imagine a region which is as little explored botanically as the area around Kwerba. Given biogeographical considerations for this relatively isolated massif (see Supriatna et al. 1999), it seems plausible, that the Foja Mountains possess a localized flora with many locally restricted endemic taxa, as seems to be the case with fauna (Diamond 1982, 1985, Beehler et al. 2007). Thus we should not be surprised to encounter various novel forms in these surveys or in those that have followed (Anonymous 2006a, b, Beehler et al. 2007). In addition, even for more widespread taxa, the limited number of previous collections in the region means that we should expect to have difficulties identifying species that may have only seldom been recorded previously and thus remain poorly characterised. Clearly much more work is needed to describe and clarify the biogeographical nature of these plant communities.

The Herbarium Bogoriense houses Indonesia's largest botanical collection, including those for Papua. One set of almost all collections made in Indonesia is kept in Bogor. 132 of our specimens could not be matched with any held at the Bogor Herbarium, this implies that they have not previously been collected in Indonesia. Some of our unnamed taxa may be new species. We can at least be sure that most are poorly known and seldom collected.

\section{Flora}

Common to other floristic overviews of the region, we find that while many species are endemic to New Guinea most of the families are widespread and possess an Asian affinity (Dipterocarpaceae, Araceae) with any distinctive 'eastern' or 'southern' elements (e.g. Sapindaceae, Myrtaceae, Myristicaceae, Flagellariaceae) being relatively minor (e.g. Roos et al. 2004). The low level of endemism at higher taxonomic levels is likely a result of the relatively young geological age of the New Guinea Islands (Morley 2000). Within the Foja and other mountains in the region diversification is likely an ongoing progress on these mountains, with endemics being young rather than old. More work is required to clarify the biogeographical history of the flora in this geologically dynamic region.

\section{Comparisons}

We sought other quantitative vegetation studies in Papua, and, finding few, in New Guinea more generally (see Table 5). We found only three published studies: Paijmans (1970), Wright et al. (1997) and Polak (2000), of which only the most recent is in Papua.

Paijmans (1970) made a comparison of four plots: two on moderately steep slopes in an area $160 \mathrm{~km}$ northeast of Port Moresby, PNG, and two on a gently sloping plateau ( 0.8 ha each). $\mathrm{He}$ found that tree density was higher, average dbh smaller but BA higher in the former plots. Paijmans recorded trees over $>12$ inch girth, or $9.8 \mathrm{~cm} \mathrm{dbh}$, only slightly smaller than the $10 \mathrm{~cm}$ $\mathrm{dbh}$ used in our study. Species overlap between plots was minimal (55\% of species recorded occurred only once or twice, 
Table 5 Comparison of stand properties and species richness in New Guinea.

\begin{tabular}{|c|c|c|c|c|c|c|c|c|}
\hline & $\mathrm{Nr}$ of plots & Plot size & $\mathrm{Nr}$ of records & Density per ha & Average $\mathrm{dbh}^{*}$ & $\mathrm{BA} \mathrm{m} \mathrm{m}^{2} / \mathrm{ha}$ & $\mathrm{Nr}$ of species & Fisher's Alpha \\
\hline This study (primary forest plots only) & 10 & Var. area & 399 & $598 \pm 136$ & $22 \pm 1.0$ & $32.4 \pm 12.0$ & 127 & 64.31 \\
\hline Paijmans 11970 & 1 & 0.8 ha & 528 & 652 & 24.9 & 29.2 & 122 & 49.75 \\
\hline Paijmans 21970 & 1 & $0.8 \mathrm{ha}$ & 560 & 691 & 26.5 & 30.5 & 147 & 64.91 \\
\hline Paijmans 31970 & 1 & 0.8 ha & 426 & 526 & 27.8 & 31.2 & 145 & 77.47 \\
\hline Paijmans 41970 & 1 & $0.8 \mathrm{ha}$ & 348 & 430 & 29.2 & 30.8 & 116 & 60.93 \\
\hline Paijmans all 1970 & 4 & 0.8 ha & 1862 & 575 & 27.1 & $29.2-31.2$ & 392 & 77.70 \\
\hline Wright et al. 1997 & 1 & 1 ha & 679 & & $21.8 \pm 14.3$ & & 222 & 114.81 \\
\hline
\end{tabular}

* Paijmans recorded trees with $\mathrm{dbh}>12$ inch $(9.8 \mathrm{~cm}$, slightly smaller than the other studies).

and only 3 species were found in all 4 plots), indicating high diversity and minimal if any grouping of species. The families Lauraceae, Meliaceae and Moraceae were best represented in terms of number of tree species and individuals.

Wright et al. (1997) recorded trees and lianas over $10 \mathrm{~cm}$ dbh in a one hectare plot in the Crater Mountain Biological Research Station on the southern scarp of the Central Range of PNG. They distinguished 228 species, the highest record from New Guinea to date. They suggest that lack of a pronounced dry season along with high topographic variation contribute to this richness. The Lauraceae family had most species, individuals and highest BA; Myristicaceae had second most individuals, and Moraceae second most species.

Polak (2000) surveyed 22 small plots ( 0.1 ha) - primary rainforest on flat to slightly undulating terrain - in the Bird's Head area, Indonesian Papua, and enumerated all plants $>10 \mathrm{~cm}$ dbh (mostly trees). Myrtaceae, Burseraceae and Euphorbiaceae were the most frequent families and Myrtaceae, Lauraceae and Meliaceae appeared most species rich.

So how does the Kwerba forest compare to others in the region? The composition and structure of Kwerba's forests are similar to Paijmans' forests of foothills and mountains below 1000 m (Paijmans 1976) and 'lowland rain forest' as described in Womersley (1978). Tree density (600 per ha) is typical for New Guinea, but at the high end of the range for lowland rainforest in Malesia including Kalimantan, Sumatra or Sulawesi (Kartawinata 1990). Basal area is typical for tropical forests $\left(25-40 \mathrm{~m}^{2}\right)$. Kwerba's tree species richness is also unremarkable compared to other regions in New Guinea, though we cannot be certain what is the effect of small plots and local and regional variation - subjects requiring further evaluation. Both the Central Range of PNG and Bird's Head seem to have richer tree floras than Kwerba (Wright et al. 1997, Polak 2000), although commentators seem to agree that such high tree species richness is uncommon in New Guinea (Paijmans 1970, Wright et al. 1997, Oatham \& Beehler 1998).

Typical canopy tree sizes (dbh and height) in Kwerba and elsewhere in New Guinea are often smaller than the forests further west (Paijmans 1976, Womersley 1978). We do not know why Papua's forests are short when compared with equatorial rainforests in other regions of the world including Sunda. As one reviewer suggests, it could reflect species composition, as many of the dominant tree families in Papua also have relatively small stature when they occur in Sunda Shelf forests. In our observations, though, we find that Dipterocarpaceae, the dominant canopy family in most Sunda Shelf forests are also common around Kwerba, but fail to reach the sizes seen in Borneo's hill forests. Even if the difference does reflect taxonomic factors it still begs the question as to why taller trees, and indeed taller taxa, are not favoured. The evolution of tree and forest stature is a topic with a rich theoretical base (see Iwasa et al. 1985, Niklas 1995, Thomas 1996, De Gouvenain \& Silander 2003, Falster \& Westoby 2003) and explanations could reflect soils, drought, or indeed the prevalence of disturbance - we do not know. The fact that Papua's flora is especially rich in pioneer species suggests that disturbance processes play a larger role in these forests than in some other tropical regions - perhaps due to both the geological and climatic instability of the region (Whitmore 1998). Support for such proposals would include regional evidence of high climatic variability and fire frequency during the middle to late Holocene - an El Niño related phenomenon that likely influenced modern vegetation patterns (Haberle et al. 2001).

\section{CONCLUSIONS}

Our study provides a first look at a previously unexplored site of considerable biological importance. The results illustrate how much remains unknown about New Guinea's vegetation. Efforts must be increased to recognise the major patterns of endemism in this region so that conservation can be planned in advance of impending threats - otherwise we may lose species and never know what we have lost. We underline the value of working with local people in this undertaking.

Acknowledgements Conservation International has a program to strengthen biodiversity conservation and environmental management in the Mamberamo area. $\mathrm{Cl}$ asked the Center for International Forestry Research (CIFOR), to train a team in carrying out surveys like the one presented here. Scott Frazier, Yosef Watoba and Tommy Wakum of Cl-Papua organised the logistics. Kwerba community members Adolof Meop, Binus Tawane, Kostan Tawane, Pilemon Karawata, Tonci Haciwa and Mrs Adorina helped guide our fieldwork. We are grateful for contributions and comments from Manuel Boissière, Nining Liswanti, Erlani Rahareng, Imam Basuki, Apresus Sinaga, John Mampioper and Michael Padmanaba. The maps were prepared by Agus Mohammad Salim of CIFOR. For other support at CIFOR, we would like to thank Markku Kanninen, Indah Susilanasari and Rina.

\section{REFERENCES}

Anonymous. 2006a. New plants found in Indonesian 'lost world'. The Garden 131, 4: 224-232. Royal Horticultural Society, UK.

Anonymous. 2006b. Plant discoveries: Palm tree is a new genus. The Garden 131, 5: 304-312. Royal Horticultural Society, UK.

Archbold R, Rand AL, Brass LJ. 1942. Results of the Archbold expeditions. No. 41. Summary of the 1938-1939 New Guinea expedition. Bulletin of the American Museum of Natural History 73: 201-288.

Beehler BM. 2007. Introduction to Papua. In: Marshall AJ, Beehler BM (eds), The ecology of Papua, Part 1: 3-13. The ecology of Indonesia series Vol. VI. Periplus Editions, Hong Kong.

Beehler BM, Prawiradilaga DM, De Fretes Y, Kemp N. 2007. A new species of Smoky Honeyeater (Meliphagidae: Melipotes) from western New Guinea. Auk 124, 3: 1000-1009.

Boissière M, Liswanti N, Padmanaba M, Sheil D. 2007. People priorities and perceptions: towards conservation partnership in Mamberamo. CIFOR, Bogor Indonesia.

Boissière $M$, Van Heist $M$, Sheil D, Basuki I, Frazier S, Ginting U, Wan M, Hariadi B, Hariyadi H, Kristianto HD, Bemei J, Haruway R, Marien ERC, Koibur DPH, Watopa Y, Rachman I, Liswanti N. 2005. Pentingnya sumberdaya alam bagi masyarakat lokal di daerah aliran sungai Mamberamo, Papua, dan implikasinya bagi konservasi. Journal of Tropical Ethnobiology 1: 76-95. 
Brummitt RK. 1992. Vascular plant families and genera. The Royal Botanic Gardens, Kew, UK.

CIFOR, CI-Papua, LIPI, 18 Papua-based Trainees, and the people of Papasena-I and Kwerba. 2004. Building capacity for multidisciplinary landscape assessment in Papua: three phases of training and pilot assessments in the Mamberamo basin. Project report. CIFOR, Bogor, Indonesia.

Cyranoski D. 2006. Calls to conserve biodiversity hotspots. Nature 439: 774.

Davis SD, Ashton PS, Johns, RJ. 1995. Regional overview: South East Asia (Malesia). In: Davis SD, Heywood VH, Hamilton AC (eds), Centres of plant diversity Vol. 2: 229-432. WWF/IUCN, Oxford, UK.

De Gouvenain RC, Silander JA. 2003. Do tropical storm regimes influence the structure of tropical lowland rain forests? Biotropica 35: 166-180.

Diamond JM. 1982. Rediscovery of the Yellowfronted Gardener Bowerbird. Science 216: 431-134.

Diamond JM. 1985. New distributional records and taxa from the outlying mountain ranges of New Guinea. Emu 85: 65-91.

Falster DS, Westoby M. 2003. Plant height and evolutionary games. Trends in Ecology \& Evolution 18: 337-343.

Fisher RA, Corbet AS, Williams CB. 1943. The relation between the number of species and the number of individuals in a random sample of an animal population. Journal of Animal Ecology 12: 4258.

Frodin D. 2001. Guide to the standard floras of the world. Second edition. Cambridge University Press, UK.

Gillison AN, Carpenter G. 1997. A generic plant functional attribute set and grammar for dynamic vegetation description and analysis. Functional Ecology 11, 6: 775-783.

Haberle SG, Hope GS, Van der Kaars S. 2001. Biomass burning in Indonesia and Papua New Guinea: natural and human induced fire events in the fossil record. Palaeogeography Palaeoclimatology Palaeoecology 171: 259-268.

Humphreys GS, Brookfield H. 1991. The use of unstable steeplands in the mountains of Papua-New-Guinea. Mountain Research and Development 11: 295-318.

Iwasa Y, Cohen D, Leon JA. 1985. Tree height and crown shape, as results of competitive games. Journal of Theoretical Biology 112: 279-297.

Kartawinata K. 1990. A review of natural vegetation studies in Malesia, with special reference to Indonesia. In: Baas P, Kalkman C, Geesink R (eds), The plant diversity of Malesia: 121-132. Kluwer Academic Publishers, Dordrecht, The Netherlands.

Marshall AJ, Beehler BM. 2007. The ecology of Papua - Part 1 and 2. The Ecology of Indonesia series Vol. VI. Periplus Editions, Hong Kong.

Mertz O. 2002. The relationship between length of fallow and crop yields in shifting cultivation: a rethinking. Agroforestry Systems 55: 149-159.

Morley RJ. 2000. Origin and evolution of tropical rain forests. Wiley \& Sons Ltd., Chichester, UK.

Niklas KJ. 1995. Size-dependent allometry of tree height, diameter and trunk-taper. Annals of Botany 75: 217-227.

Oatham M, Beehler BM. 1998. Richness, taxonomic composition, and species patchiness in three lowland forest tree plots in Papua New Guinea. Proceedings of the international symposium for measuring and monitoring forests and biological diversity; the International Networks of Biodiversity Plots. Smithsonian Institute Man and the Biosphere Biodiversity Program (SIIMAB).

Paijmans K. 1970. An analysis of four tropical rain forest sites in New Guinea. The Journal of Ecology 58: 77-101.
Paijmans K. 1976. New Guinea vegetation. Australian National University Press, Canberra.

Polak M. 2000. The botanical diversity in the Ayawasi area, Irian Jaya, Indonesia. Biodiversity and Conservation 9: 1345-1375.

Richards SJ, Suryadi S (eds). 2002. A biodiversity assessment of Yongsu Cyclops mountains and the southern Mamberamo basin, Papua, Indonesia. RAP Bulletin of Biological Assessment 25. Cl, Washington, DC, USA.

Roos MC, Keßler PJA, Gradstein SR, Baas P. 2004. Species diversity and endemism of five major Malesian islands: diversity-area relationships. Journal of Biogeography. 31: 1893-1908.

Sheil D, Boissière M. 2006. Local people may be the best allies in conservation. Nature 440: 868.

Sheil D, Ducey MJ, Sidiyasa K, Samsoedin I. 2003a. A new type of sample unit for the efficient assessment of diverse tree communities in complex forest landscapes. Journal of Tropical Forest Science 15: 117-135.

Sheil D, Lawrence A. 2004. Tropical biologists, local people and conservation: new opportunities for collaboration. Trends in Ecology and Evolution 19: 634-638.

Sheil D, Liswanti N, Basuki I, Wan M, Samsoedin I, Kartawinata K, Rukmiyati, Agung M. 2003b. Prioritas lokal dan keanekaragaman hayati dalam lansekap hutan: apa penting menurut masyarakat? Jurnal Hutan Indonesia. August -4 page pull out (no page numbers).

Sheil D, Puri RK, Basuki I, Van Heist M, Syaefuddin, Rukmiyati, Sardjono MA, Samsoedin I, Sidiyasa K, Chrisandini, Permana E, Angi EM, Gatzweiler F, Johnson B, Wijaya A. 2003c. Exploring biological diversity, environment and local people's perspectives in forest landscapes. CIFOR, Bogor, Indonesia. http://www.cifor.cgiar.org/mla/download/publication/exploring_bio.pdf [accessed 31 December 2008].

Sheil D, Puri RK, Wan M, Basuki I, Van Heist M, Liswanti N, Rukmiyati, Rachmatika I, Samsoedin I. 2005. Local people's priorities for biodiversity: examples from the forests of Indonesian Borneo. Ambio 35, 1: 17-24.

Sheil D, Sayer JA, O'Brien T. 1999. Tree diversity and conservation in logged rainforest. Science 284: 1587.

Subagjo H, Suharta N, Siswanto AB. 2000. Lahan pertanian Indonesia (Agricultural lands of Indonesia). In: Sumberdaya lahan Indonesia dan pengelolaannya (Land resources in Indonesia and their management): 21-66. Center for Soil and Agroclimate Research and Development, Bogor.

Supriatna J, De Fretes Y, Mack A, Yeager CP, Olivieri S, Burnett JB, Wijayanto I, Suryadi S, Suhandi A (eds). 1999. The Irian Jaya biodiversity conservation priority-setting workshop. Final report. Conservation International, Washington, DC.

Suwardi, Wiranegara. 1998. Penuntun praktikum klasifikasi dan morfologi tanah. Institut Pertanian, Bogor, Indonesia. (Practical guide for the classification and morphology of soils. Agricultural Institute of Bogor, Indonesia).

Thomas SC. 1996. Asymptotic height as a predictor of growth and allometric characteristics Malaysian rain forest trees. American Journal of Botany 83: $556-566$.

Whitmore TC. 1998. An introduction to tropical rain forests (second edition). Oxford University Press, UK.

Womersley JS (ed). 1978. Handbooks of the flora of Papua New Guinea, Vol. I. Melbourne University Press, Australia.

Wright D, Heinrich Jessen J, Burke P, Gomez de Silva Garza H. 1997. Tree and liana enumeration and diversity on a one-hectare plot in Papua New Guinea. Biotropica 29: 250-260.

Appendix A List of plot characteristics, Kwerba village.

\begin{tabular}{|c|c|c|c|c|c|c|c|c|}
\hline Plot & $\begin{array}{l}\text { Location } \\
\text { (Local Name) }\end{array}$ & East $\left(\mathrm{utm}^{*}\right)$ & North (utm) & Alt. $\left(\right.$ masl $\left.^{\star *}\right)$ & Terrain type & Soil & Vegetation type & Human influences \\
\hline $\mathrm{F} 1$ & Abbua & 212825 & 9708063 & 100 & Footslope $20 \%$ & Inceptisol & Primary forest & Trail \\
\hline $\mathrm{F} 2$ & Pitiuw & 211872 & 9706558 & 107 & Footslope, $10 \%$ & Inceptisol & Primary forest & Cut stems, trail \\
\hline F3 & Momorokoe & 212310 & 9709039 & 82 & Flat, riverside & Inceptisol & Primary forest & Cut stems, trail \\
\hline $\mathrm{F} 4$ & Navaci & 200904 & 9715019 & 71 & Undulating & Inceptisol & Primary forest & Cut stems, trail \\
\hline F5 & Kwikarawar & 213202 & 9708267 & 190 & Hilly, shoulder & Ultisol & Primary forest & Cut stems, trail \\
\hline F6 & Hehetemenem & 214183 & 9712372 & 210 & Undulating, on lake side & Entisol & Lake side forest & Cut stems, trail \\
\hline $\mathrm{F} 7$ & Kerenebu & 213237 & 9707997 & 125 & Footslope, $15 \%$ & Inceptisol & Primary forest & Cut stems, trail \\
\hline F8 & Laperem & 212351 & 9709537 & 230 & Hilly, $30 \%$ & Ultisol & Primary forest & Cut stems, trail \\
\hline F9 & Wirinya & 211438 & 9706477 & 75 & Flat & Ultisol & Primary forest & Cut stems, trail \\
\hline F10 & Taciwaram & 212117 & 9708221 & 84 & Flat & Inceptisol & Primary forest & Cut stems, trail \\
\hline $\mathrm{C} 1$ & Anakwaciauw & 211885 & 9706927 & 89 & Flat & Inceptisol & Fallow 6 yrs & Former cultivation, trail \\
\hline $\mathrm{C} 2$ & Taciwaram & 211225 & 9707036 & 61 & Flat & Inceptisol & Old fallow $>20$ yrs & Former cultivation (1978?), trail \\
\hline $\mathrm{C} 3$ & Anakwaciaw & 211968 & 9707163 & 90 & Flat & Inceptisol & Old fallow $>20$ yrs & Former cultivation (1977?), fire, trail \\
\hline $\mathrm{C} 4$ & Paquimya & 211280 & 9707684 & 280 & Flat & Entisol & $\begin{array}{l}\text { Garden / mixed } \\
\text { secondary forest }\end{array}$ & $\begin{array}{l}\text { Cultivation since 1989, cut stems, } \\
\text { trail }\end{array}$ \\
\hline C5 & Dusun sagu & 212930 & 9708749 & 13 & Flat, swampy & Entisol & Sago garden $>20$ yrs & Trail \\
\hline
\end{tabular}

* Universal Transverse Mercator, a metric coordinate system for locating plots.

** Altitude in meters above sea level. 
Appendix B Forest structure of all plots, by cover type.

\begin{tabular}{|c|c|c|c|c|c|c|c|c|c|c|}
\hline Plot & $\begin{array}{l}\text { Density } \\
\text { per ha }\end{array}$ & $\mathrm{BA} \mathrm{m} \mathrm{m}^{2} / \mathrm{ha}$ & $\begin{array}{l}\text { Average } \\
\mathrm{dbh}(\mathrm{cm})\end{array}$ & $\begin{array}{l}\text { Max } \\
\text { dbh (cm) }\end{array}$ & $\begin{array}{l}\text { Average } \\
\mathrm{Ht}(\mathrm{m})\end{array}$ & $\begin{array}{l}\text { Average } \\
\text { F-index }\end{array}$ & $\begin{array}{l}\text { StdDev } \\
\text { F-index }\end{array}$ & $\begin{array}{l}\text { Nr of tree } \\
\text { species }^{*}\end{array}$ & $\begin{array}{l}\text { Log Nr spec / } \\
\text { Log Nr stems }\end{array}$ & $\mathrm{Nr}$ of herbs etc. ${ }^{1}$ \\
\hline \multicolumn{11}{|c|}{ Primary forest } \\
\hline $\mathrm{F} 1$ & 767 & 61.6 & 23.8 & 110 & 18.8 & 6 & 13.5 & 19 & 0.80 & 90 \\
\hline $\mathrm{F} 2$ & 545 & 30.7 & 22.2 & 65 & 23 & 7.7 & 13.5 & 26 & 0.88 & 64 \\
\hline F3 & 469 & 26.6 & 21.7 & 60 & 21.9 & 16.3 & 18.8 & 28 & 0.90 & 60 \\
\hline $\mathrm{F} 4$ & 523 & 21.7 & 20.9 & 52.4 & 17.3 & 14.2 & 23.3 & 20 & 0.81 & 36 \\
\hline F5 & 775 & 38.6 & 21.1 & 57.7 & 21.7 & 12.0 & 12.0 & 20 & 0.81 & 31 \\
\hline $\mathrm{F} 6$ & 779 & 37.7 & 23.1 & 51.1 & 22.6 & 17.3 & 19.1 & 21 & 0.83 & 43 \\
\hline $\mathrm{F} 7$ & 496 & 22.2 & 20.9 & 59 & 24.3 & 3.4 & 13.4 & 17 & 0.77 & 59 \\
\hline F8 & 588 & 27.2 & 21.4 & 63.7 & 19.6 & 12.9 & 11.8 & 21 & 0.83 & 43 \\
\hline F9 & 634 & 34.6 & 22.9 & 60 & 22.3 & 21.6 & 24.0 & 25 & 0.87 & 49 \\
\hline F10 & 406 & 23.4 & 22.2 & 60 & 18.6 & 7.3 & 13.2 & 24 & 0.87 & 52 \\
\hline Average & 598.2 & 32.4 & 22.0 & 63.9 & 21.0 & 11.9 & 16.3 & 22.1 & 0.8 & 52.7 \\
\hline Std dev. & 136.0 & 12.0 & 1.0 & 16.8 & 2.3 & 5.7 & 4.7 & 3.5 & 0.04 & 16.9 \\
\hline \multicolumn{11}{|c|}{ Former cultivation ${ }^{2}$} \\
\hline C1 (6yrs) & 892 & 19.5 & 16.3 & 29 & 11.8 & 49.85 & 45.49 & $14(1)$ & 0.70 & 40 \\
\hline C3 (>20yrs) & 637 & 16.2 & 16.9 & 40 & 12.9 & 52.65 & 42.44 & 11 & 0.65 & 50 \\
\hline Average & 676.3 & 19.2 & 18.0 & 41.3 & 13.0 & 38.9 & 38.3 & 15.7 & 0.7 & 52.0 \\
\hline Std dev. & 198.9 & 2.9 & 2.4 & 13.1 & 1.3 & 21.5 & 10.0 & 6.4 & 0.1 & 13.1 \\
\hline \multicolumn{11}{|l|}{ Cultivation $^{3}$} \\
\hline $\mathrm{C} 4$ & 306 & 11.7 & 20.2 & 33.5 & 14.3 & 28.91 & 40.12 & $14(4)$ & 0.75 & 41 \\
\hline C5 & 165 & 8.7 & 23.8 & 43 & 11.9 & 32.83 & 43.8 & $6(1)$ & 0.58 & 39 \\
\hline Average & 235.5 & 10.2 & 22.0 & 38.3 & 13.1 & 30.9 & 42.0 & 7.5 & 0.7 & 40.0 \\
\hline Std dev. & 99.7 & 2.1 & 2.6 & 6.7 & 1.7 & 2.8 & 2.6 & 3.5 & 0.1 & 1.41 \\
\hline
\end{tabular}

* between brackets: number of planted tree species.

1 in $200 \mathrm{~m}^{2}$ plot.

2 In plot C1, 1 of 40 trees recorded was a planted one, and has not been included in species richness summaries.

3 In plot C4, 12 of 33 trees recorded were planted; in plot C5, 8 of 24 .

Appendix C The three most abundant tree species in each plot (including planted stems).

\begin{tabular}{|c|c|c|c|c|c|c|}
\hline \multicolumn{7}{|l|}{ Plot } \\
\hline \multicolumn{7}{|c|}{ Primary forest } \\
\hline $\mathrm{F} 1$ & Cleistanthus myrianthus Kurz & 6 & Vatica rassak Blume & 2 & Diospyros sp. & \\
\hline $\mathrm{F} 2$ & Teijsmanniodendron bogoriense Koord. & 5 & $\begin{array}{l}\text { Cryptocarya sp. } 2 \text { / Mastixiodendron } \\
\text { pachyclados Melch. }\end{array}$ & 2 & Horsfieldia sylvestris Warb. & (6. \\
\hline F3 & Pimelodendron amboinicum Hassk. & 6 & Calophyllum peekelii Lauterb. & 2 & Medusanthera laxiflora (Miers) R.A.Howard. & 4 \\
\hline $\mathrm{F} 4$ & $\begin{array}{l}\text { Teijsmanniodendron hollrungii (Warb.) } \\
\text { Kosterm. }\end{array}$ & 4 & Drypetes celebica Pax \& K.Hoffm. & 1 & $\begin{array}{l}\text { Myristica fatua Houtt. I } \\
\text { Canarium sp. } 1\end{array}$ & 2 \\
\hline F5 & Hopea novoguineensis Slooten & 6 & $\begin{array}{l}\text { Teijsmanniodendron hollrungii (Warb.) } \\
\text { Kosterm. }\end{array}$ & 5 & Canarium maluense Lauterb. & 5 \\
\hline F7 & $\begin{array}{l}\text { Teijsmanniodendron hollrungii (Warb.) } \\
\text { Kosterm. }\end{array}$ & $4^{*}$ & Canarium maluense Lauterb. & 5 & Diospyros buxifolia Hiern & 2 \\
\hline F8 & $\begin{array}{l}\text { Teijsmanniodendron hollrungii (Warb.) } \\
\text { Kosterm. }\end{array}$ & 5 & Maniltoa schefferi K.Schum. & 1 & Horsfieldia sylvestris Warb. & 3 \\
\hline F9 & Mastixiodendron pachyclados Melch. & 1 & Myristica sp. & 4 & Intsia bijuga Kuntze & 6 \\
\hline F10 & Pimelodendron amboinicum Hassk. & 6 & Mastixiodendron pachyclados Melch. & 2 & $\begin{array}{l}\text { Intsia bijuga Kuntze / } \\
\text { Gnetum gnemon L. }\end{array}$ & 6 \\
\hline F6 & $\begin{array}{l}\text { Teijsmanniodendron hollrungii (Warb.) } \\
\text { Kosterm. }\end{array}$ & 4 & Cleistanthus myrianthus Kurz & 6 & Pimelodendron amboinicum Hassk. & $\epsilon$ \\
\hline \multicolumn{6}{|c|}{ Former cultivation } & \\
\hline $\mathrm{C} 1$ & $\begin{array}{l}\text { Anisoptera thurifera Blume ssp. polyandra } \\
\text { (Blume) P.S.Ashton }\end{array}$ & 1 & Alphitonia incana (Roxb.) Kurz & 1 & Glochidion weberi C.B.Rob. & \\
\hline $\mathrm{C} 2$ & Ficus variegata Blume & 7 & Pometia pinnata Forst. & 1 & Colona scabra Burret & 2 \\
\hline C3 & Glochidion novo-guineense K.Schum. & 3 & Ficus miquelii King & 2 & Ficus variegata Blume & 7 \\
\hline \multicolumn{6}{|c|}{ Cultivation } & \\
\hline $\mathrm{C} 4$ & Gulubia costata (Becc.) Becc. & 1 & (Cocos nucifera L. / Theobroma cacao L.) & 1 & Ficus ruficaulis Merr. & \\
\hline C5 & Adina sp. & 1 & Metroxylon sagu Rottb. & 1 & Nauclea sp. & 1 \\
\hline
\end{tabular}

* the numbers in the bottom right of each cell indicate the number of plots (out of 15) in which the species was recorded. 